\title{
METODE PENGEMBANGAN INSTRUMEN PENGUKUR KECERDASAN SPIRITUAL MAHASISWA
}

\author{
Rijal Firdaos \\ IAIN Raden Intan Lampung, Lampung, Indonesia \\ rijalfirdaos@radenintan.ac.id
}

\begin{abstract}
Abstrak
Tujuan utama penelitian ini adalah untuk memberikan informasi terkait bagaimana mengembangkan instrumen untuk mengukur kecerdasan spiritual mahasiswa. Adapun tujuan khususnya adalah: 1) mengetahui konsep pengembangan instrumen, 2) mengetahui prosedur pengembangan instrumen, 3) dan mengetahui metode pengujiannya. Penelitian ini menggunakan jenis penelitian kepustakaan dengan menelaah berbagai literatur sebagai sumber pendukung. Hasil penelitian menujukkan bahwa; pertama, instrumen memegang peranan yang sangat penting dalam menentukan mutu suatu penelitian, sekaligus alat bantu yang digunakan oleh peneliti untuk mengumpulkan data dengan cara melakukan pengukuran. Kedua, prosedur pengembangan instrumen melewati beberapa tahap, mulai dari tahap mengembangkan definisi konseptual, pemberian skala, rewiew justifikasi butir, menyiapkan draf instrumen, pengumpulan data uji coba, dan analisis data uji coba. Ketiga, metode pengujian yang digunakan untuk mengembangkan instrumen adalah analisis faktor dengan menggunakan bantuan software SPSS dan Lisrel.
\end{abstract}

Kata kunci: metode, pengembangan instrumen, kecerdasan spiritual 


\section{Abstract}

SPIRITUAL INTELLIGENCE MEASUREMENTS INSTRUMENT DEVELOPING METHODS. The main objective of this study is to provide information related how to develop a spiritual instrument to measure the intelligence of students. The specific objectives are: 1) understanding the instrumental development concept, 2) knowing the instrumental development procedure, 3) and determining the testing method. This study used library research by examining the literature as a supporting source. The results of study show that first, the instrument plays a very important role to determine the quality of a study, as well as become the tools used by researcher to collect the data by conducting measurements. Second, the instrumental development procedure passes several stages; those are developing the conceptual definition, giving scale, reviewing the justification points, preparing instrumental draft, collecting the trial data, and analyzing the trial data. Third, the testing method used to develop the instrument is factor analysis by using SPSS and Lisrel.

Keywords: method, instrument development, spiritual intelligence

\section{A. Pendahuluan}

Penelitian terhadap pengembangan skala instrumen keagamaan secara khusus belum begitu banyak dilakukan. Penelitian terhadap spiritual sejauh ini dilakukan untuk tujuan mengetahui tingkat spiritual seseorang, atau untuk mencari hubungan/pengaruh dengan faktor lain yang memiliki keterkaitan terhadap sikap seseorang dengan keyakinan keagamaannya.

Albelaikhi (1997), misalnya, melakukan penelitian tentang Development of Moslem Religiosity Scale. Peneliti menggunakan pendekatan Principal Component Analysis yang diujicobakan kepada 169 pelajar muslim di Arab Saudi. Dari hasil penelitiannya, diperoleh enam dimensi yang telah memiliki kualitas butir instrumen yang baik. Keenam dimensi tersebut adalah: dimensi praktik, dimensi sosial keagamaan, dimensi keyakinan, dimensi kebutuhan diri terhadap agama, dimensi penerimaan, dan dimensi kebutuhan terhadap pedoman (Kitab).

Cotton, dan McGrady (2010) mempublikasikan hasil penelitian tentang tentang Measurement of Religiosity in Adolescent Health Outcome Research: Trends and Recommendations. Penelitian 
yang menggunakan metode survei tersebut, menyebutkan terdapat lima kunci dimensi religiusitas yang dijadikan sebagai bahan instrumen dalam penelitiannya. Di antara dimensi yang dimaksud adalah: dimensi pemahaman terhadap agama, dimensi kontrol diri, dimensi kenyamanan diri, dan dimensi pengalaman.

Lain halnya dengan Harris dan Shrier (2007) melakukan penelitian tentang Reliability and Validity of the brief Multidimensional Measure of Religiousness/Spirituality among Adolescent. Hasil penelitian yang menggunakan Skala Likert tersebut dilakukan terhadap 305 responden dengan usia remaja antara 12-18 tahun. Hasil penelitian mengindikasikan bahwa terdapat $11 \%$ yang tidak bertuhan (atheis), $9 \%$ tidak tahu, dan sisanya $80 \%$ menyatakan beragama sesuai dengan keyakinan masing-masing.

Di Indonesia, kajian bidang keagamaan sudah banyak dilakukan dengan berbagai pendekatan. Menurut Suprayogo (2003: 16), konsep penelitian agama bisa menimbulkan beberapa pengertian. Pertama, penelitian agama berarti mencari agama atau mencari kembali kebenaran suatu agama atau dalam rangka menemukan agama yang dianggap paling benar. Dalam pengertian ini, penelitian agama berarti mencari kebenaran substansi agama sebagaimana dilakukan para nabi, pendiri, atau pembaru suatu agama.

Kedua, penelitian agama berarti metode untuk mencari kebenaran agama atau usaha untuk menemukan dan memahami agama sebagai realitas empiris dan bagaimana penyikapan terhadap realitas tersebut. Di sini agama sebagai subject matter atau sasaran penelitian. Ketiga, penelitian agama berarti meneliti fenomena sosial yang ditimbulkan oleh agama dan penyikapan masyarakat terhadap agama.

Merujuk dari pandangan di atas, perlu kiranya kajian tentang keagamaan melebarkan sayapnya pada pengujianpengujian sebuah teori yang ada, menjadi sebuah konstruk, yang kemudian diuji secara empiris menggunakan pendekatan kuantitatif, terlebih pada konteks bagaimana mengembangkan skala untuk kebutuhan mengukur sikap seseorang terhadap gejala yang ditimbulkan. 
Tujuan utama penelitian ini adalah untuk memberikan informasi terkait bagaimana metode mengembangkan instrumen pengukur kecerdasan spiritual mahasiswa. Adapun tujuan khususnya adalah untuk mengetahui konsep pengembangan instrumen, mengetahui prosedur pengembangan instrumen, dan mengetahui metode pengujiannya.

\section{B. Pembahasan}

\section{Konsep Pengembangan Instrumen}

Instrumen memegang peranan yang sangat penting dalam menentukan mutu suatu penelitian. Karena validitas atau kesahihan data yang diperoleh akan sangat ditentukan oleh kualitas atau validitas instrumen yang digunakan, di samping prosedur pengumpulan data yang ditempuh. Menurut Kothari (2004: 73) hal ini mudah dipahami karena instrumen berfungsi mengungkapkan fakta menjadi data, sehingga jika instrumen yang digunakan mempunyai kualitas yang memadai dalam arti valid dan reliabel maka data yang diperoleh akan sesuai dengan fakta atau keadaan sesungguhnya di lapangan.

Instrumen merupakan alat bantu yang digunakan oleh peneliti untuk mengumpulkan data dengan cara melakukan pengukuran. Cara ini dilakukan untuk memperoleh data yang objektif yang diperlukan untuk menghasilkan kesimpulan penelitian yang objektif pula (Purwanto, 2010: 183). Menurut Colton dan Covert (2007: 5), Instrument is a mechanism for measuring phenomena, which is used to gather and record information for assessment, decision making, and ultimately understanding. Instrumen seperti halnya kuesioner merupakan salah satu bagian yang digunakan untuk memperoleh informasi yang faktual, mengobservasi, atau menilai suatu sikap dan opini.

Adapun ilmu pengukuran (measurement) adalah cabang dari ilmu statistika terapan yang bertujuan membangun dasar-dasar pengembangan tes yang lebih baik sehingga dapat menghasilkan tes yang berfungsi secara optimal, valid, dan reliabel. Dasar-dasar pengembangan tes tersebut dibangun di atas 
model-model matematik yang secara berkesinambungan terus diuji kelayakannya oleh ilmu psikometri (Azwar, 2005: 3).

Secara operasional, pengukuran merupakan suatu prosedur pembandingan antar atribut yang hendak diukur dengan alat ukurnya. Di antara karakteristik pengukuran yaitu; pertama, merupakan pembanding antara atribut yang diukur dengan alat ukurnya, kedua, hasilnya dinyatakan secara kuantitatif, dan ketiga, hasilnya bersifat deskriptif. Ketiga karakteristik tersebut, tentunya menjadi bagian yang tidak terpisahkan dalam setiap kegiatan pengukuran.

Ilmu pengukuran termasuk ke dalam kategori penelitian yang bersifat kuantitatif. Kelebihan dari pendekatan ini dalam pandangan Camic (2003: 42) karena mampu menyediakan kualitas penilaian sebuah informasi secara ekplisit, yang diperoleh dari studi tertentu. Di samping itu, teknik penelitian kuantitaif juga sering digunakan untuk mendesain bagaimana mengungkapan sebuah teori, menyoal seputar reliabilitas, validitas, dalam suatu sistem pengukuran terhadap fenomena yang akan dikaji.

Dalam konteks pengembangan instrumen, Gable (1986: 170) memberikan garis besar 15 langkah kerja yang harus ditempuh dalam mengembangkannya, yaitu sebagai berikut: (1) mengembangkan definisi konseptual, (2) mengembangkan definisi operasional, (3) memilih teknik pemberian skala, (4) melakukan review justifikasi butir, yang berkaitan dengan teknik pemberian skala yang telah ditetapkan, (5) memilih format respons atau ukuran sampel, (6) menyusun petunjuk untuk respons, (7) menyiapkan draf instrumen, (8) menyiapkan instrumen akhir, (9) pengumpulan data uji coba awal, (10) analisis data uji coba dengan menggunakan teknik analisis faktor, analisis butir, dan reliabilitas, (11) revisi instrumen, (12) melakukan ujicoba final, (13) menghasilkan instrumen, (14) melakukan analisis validitas dan reliabilitas tambahan, dan (15) menyiapkan manual tes.

Dengan demikian, pengembangan instrumen merupakan kegiatan pengembangan terhadap konseptual teoritik yang disusun sesuai dengan konstruk dengan tujuan untuk menghasilkan sebuah instrumen baku yang mengacu kepada teknik-teknik yang sudah ditetapkan oleh para pakar secara bertahap dan proporsional. 
Pengembangan instrumen membutuhkan teori yang kuat untuk mendasari sebuah konstruk terhadap fenomena yang akan diukur, bagi lahirnya instrumen yang baik dan relevan.

\section{Step In The Instrument Construction Process}

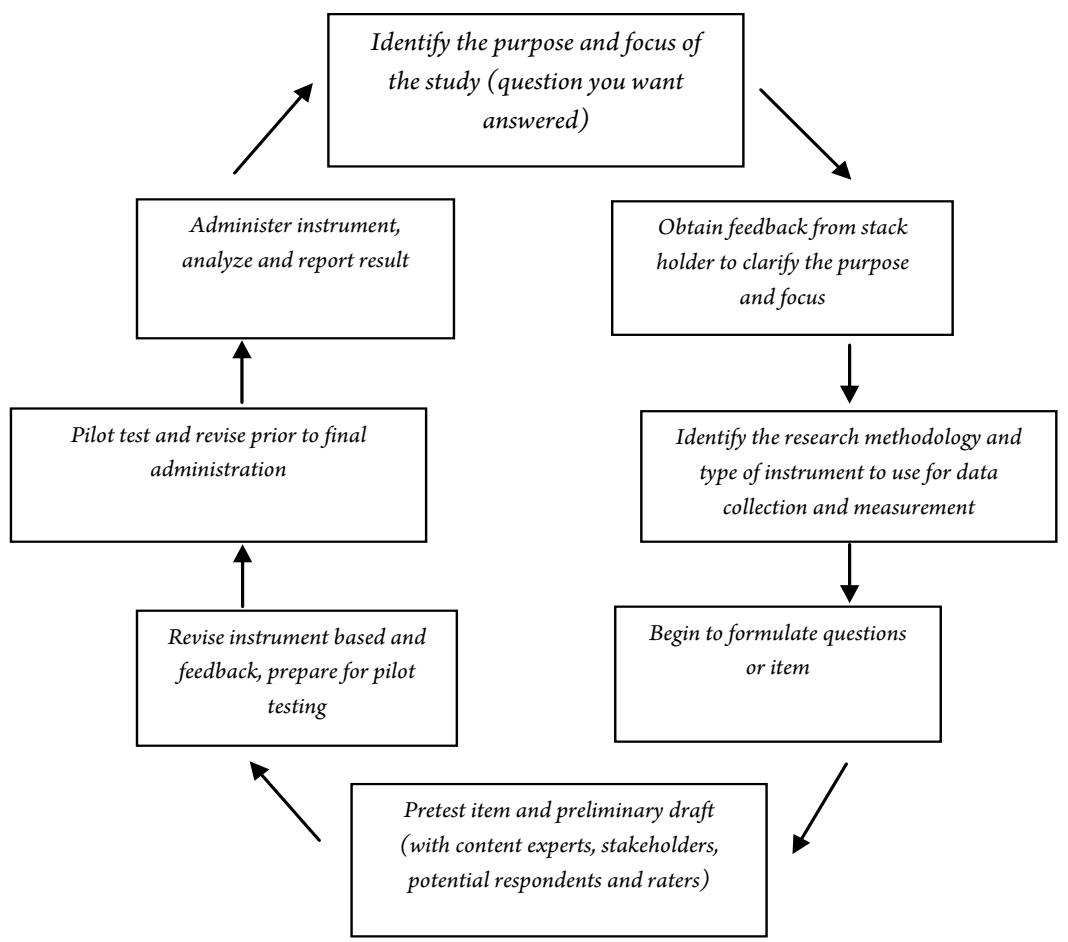

Gambar 1.1 Tahapan Proses Pengembangan Instrumen

Gambar di atas menjelaskan kepada kita, bahwa untuk memperoleh sebuah alat ukur, mulai dari menentukan tujuan dan fokus yang ingin dicapai, memilih metode yang tepat sesuai dengan jenis datanya, sampai pada bagaimana membuat administrasi instrument, dan menganalissinya sebagai hasil laporan penelitian. Hal ini dimaksudkan agar kita dapat mempersiapkan sejauh mana teori-teori yang kita pilih dapat sesuai dengan variabel yang akan dikembangkan.

\section{Konstruk, Dimensi, dan Indikator Variabel}

Setelah peneliti menentukan variabel yang akan dikembangkan, tahap selanjutnya adalah membuat konstruk, 
dimensi, dan indikator variabel. Di antara tujuan terbentuknya konstruk, dimensi dan indikator adalah, di samping memastikan terhadap sejumlah teori yang mendasarinya, juga merupakan media untuk mempermudah serta memperjelas dalam membuat formulasi sejumlah butir item yang akan dikembangkan.

Menurut Abel dan Springer (2009: 17) konstruk merujuk kepada karakteristik yang tidak bisa diamati, yang di dalamnya meliputi abstrak yang hanya bisa dipahami melalui pertanyaan kepada individu untuk memberikan informasi terkait karakteristik tersebut. Suatu konstruk adalah konsep. Akan tetapi dengan pengertian tambahan, yakni ia diciptakan atau digunakan dengan kesengajaan dan kesadaran penuh bagi suatu maksud ilmiah yang khusus. Intelegensi, misalnya, adalah suatu konsep, suatu abstraksi dari observasi tentang ihwal yang dianggap atau diduga sebagai perilaku cerdas/intelegen dan yang non intelegen (Kerlinger, 2004: 48).

Variabel kecerdasan spiritual merupakan variabel penelitian yang merupakan sintesis dari teori-terori yang dikaji dan dianalisis dalam kajian teori. Untuk mengukur kecerdasan spiritual, perlu didefinisikan terlebih dahulu apa itu kecerdasan spiritual. Untuk mengukur definisi kecerdasan spiritual diperlukan sejumlah teori. Menurut Sutrisno Hadi (1986: 13) jika bangunan teorinya sudah benar, maka hasil pengukuran yang menggunakan alat pengukur yang berbasis pada teori itu dipandang valid. Konstruk tersebut kemudian dijelaskan dalam definisi konseptual dan definisi operasional yang di dalamnya tercakup dimensi, dan indikator dari variabel yang hendak diukur. Butir-butir pertanyaan yang secara langsung diturunkan dari setiap indikator, di mana dari tiap indikator dapat dikembangkan menjadi beberapa butir pernyataan atau pertanyaan.

Kecerdasan spiritual adalah atribut psikologis yang tidak dapat diukur secara langsung. Suryabrata (2000: 177), atribut psikologis tidak dapat diukur secara langsung, melainkan dapat diukur secara tidak langsung melalui respons yang dibuat oleh subyek, pada waktu subyek dihadapkan kepada perangsang tertentu. Karena itu, setiap alat ukur psikologis dilengkapi dengan penskalaan. Dengan penskalaan dimaksudkan untuk memberikan 
angka perolehan yang dapat mengukur seberapa jauh seseorang memiliki ciri-ciri yang ingin diteliti.

\section{Prosedur Pengembangan Instrumen}

Proses pengembangan item untuk berbagai macam bentuk tes meliputi beberapa tahap. Adapun penelitian ini merupakan penelitian di bidang pengembangan instrumen yang terdiri dari tiga tahap utama yaitu: (1) tahap pengembangan instrumen, (2) tahap uji coba, dan (3) tahap pelaporan hasil untuk tujuan pengadministrasian tes, (Haladyna, 2004: 97). Tahap pengembangan instrumen merupakan tahap penyusunan perangkat tes, dimulai dari rancanagan spesifikasi tes, yang melibatkan para pakar dan praktisi di bidangnya. Pada tahap uji coba, rancangan perangkat tes yang telah dikembangkan tersebut dikalibrasi baik melalui pengujian secara rasional, maupun secara empiris. Hasil uji coba digunakan untuk penyempurnaan perangkat tes.

Selanjutnya, dilakukan penyusunan laporan hasil perangkat tes yang telah disempurnakan untuk tujuan pembukuan. Secara lebih rinci, pengembangan instrumen kecerdasan spiritual dilakukan melalui langkah-langkah sebagai berikut: a) Pengembangan definisi konseptual dan operasional dari variabel kecerdasan spiritual, b) Butir-butir kecerdasan spiritual mahasiswa disusun berdasarkan konsep yang telah diuraikan pada bagian kajian teoritik, c) Tahap pertama dari penyusunan dan pengembangan instrumen adalah pemilihan butir berdasarkan evaluasi kualitatif yang dikerjakan oleh suatu panel ahli dalam bidang atribut yang hendak diukur, dengan menggunakan Skala tertentu. Jika kita menggunakan skala Thurstone, misalnya, maka setelah seluruh item dilakukan penilaian oleh seluruh penilai atau judges, maka langkah selanjutnya adalah melakukan tabulasi data untuk menghitung frekuensi, menghitung persentase, dan persentase kumulatif untuk mencari suatu nilai yang mewakili rating dari sekelompok penilai terhadap stimulus bersangkutan. Nilai dimaksud diestimasi lewat harga mediannya yang dalam hal ini diberi lambang $S$, dengan rumus: $S=b b+I[(0,50-p k b) / p]$. Di samping itu, untuk memilih pernyataan-pernyataan terbaik, 
di samping menghitung nilai $S$ peneliti juga menghitung nilai Q. Nilai Q merupakan indikator penyebaran penilaian dari $50 \%$ anggota kelompok penilai. Dengan kata lain, nilai $\mathrm{Q}$ merupakan ukuran variasi distribusi penilaian dari $50 \%$ kelompok penilai terhadap suatu pernyataan. Nilai $Q$ dihitung sebagai: $Q=C 75$ C25; d) Revisi butir instrumen. Hal ini dimaksudkan untuk memperbaiki instrumen berdasarkan hasil telaah pakar. Telaah pakar itu berkaitan dengan validitas isi yang diestimasikan melalui pengujian terhadap isi tes dengan menggunakan analisis rasional dan professional judgement, mencakup validitas, reliabilitas, kelayakan dan keterbacaan; e) Perbaikan tes, berdasarkan hasil uji coba secara rasional; f) Ujicoba awal/terbatas pada mahasiswa untuk melihat kelayakan dan keterbacaan perangkat alat ukur, termasuk penyempurnaannya; g) Uji coba secara empiris tahap pertama, yaitu pelaksanaan tes pada sejumah mahasiswa yang terpilih sebagai sampel penelitian; h) Analisis data uji coba dengan menggunakan Analisis Faktor. Analisis faktor adalah sebuah bentuk analisa data untuk mendefinisikan struktur suatu data matrik dan menganalisis struktur saling hubungan (korelasi) antarsejumlah besar variabel dalam hal ini variabel Kecerdasan spiritual. Melalui Analisis Faktor, peneliti mengidentifikasi dimensi suatu struktur dan kemudian menentukan sampai seberapa jauh setiap variabel dapat dijelaskan oleh setiap dimensi; i) Perbaikan instrumen, dilakukan berdasarkan hasil uji coba secara empiris tahap pertama; j) Uji coba empiris tahap kedua terhadap mahasiswa yang terpilih sebagai sampel penelitian pada tahap kedua; k) Penyempurnaan instrumen, dilakukan berdasarkan hasil uji coba secara empiris tahap kedua.

\section{Metode Pengujian Instrumen Kecerdasan Spiritual}

Kecerdasan spiritual adalah kecerdasan untuk menghadapi dan memecahkan persoalan makna dan nilai, yaitu kecerdasan untuk menempatkan perilaku dan hidup kita dalam konteks makna yang lebih luas dan kaya, kecerdasan untuk menilai bahwa tindakan atau jalan hidup seseorang lebih bermakna dibandingkan dengan yang lain, Zohar dan Marshall (2007: 4). 
Variabel kecerdasan spiritual merupakan variabel laten yang tidak dapat diamati secara langsung, melainkan dengan pendekatan pengujian secara pendekatan konstruk. Meski demikian, konstruk memiliki keterkaitan teori antara satu dengan lainnya (Harrington, 2009: 50). Pengujian validitas konstruk merupakan proses yang terus berlanjut sejalan dengan perkembangan konsep mengenai trait yang diukur. Walaupun pengujian validitas konstruk biasanya memerlukan teknik analisis statistika yang yang lebih kompleks daripada teknik-teknik yang dipakai pada pengujian vaiditas empirik lainnya, akan tetapi hasil estimasi validitas konstruk tidak dinyatakan dalam bentuk suatu koefisen validitas.

Validitas merupakan kriteria atau indikator untuk menentukan sejauh mana sebuah instrumen tersebut seharusnya diukur (Kothari, 2004: 74). Validitas juga menunjukkan sejauh mana sebuah tes dianggap baik sesuai dengan desain pengukuran (Kurpius, 2006: 141). Validitas dalam konteks penelitian kuantitatif tentu berbeda dengan validitas dalam pendekatan kualitatif.

Hal tersebut sebagaimana dikemukakan Patton (1990: 14), sebagai berikut: jika dalam penelitian kualitatif the researcher is the is instrument, maka dalam konteks penelitian kuantitatif, "Validity in quantitative research depend on careful instrument construction to be sure that instrument measures what it supposed to measure. The instrument must then be administered in an appropriate, standardize manner according to prescribe procedures. The focus is on the measuring instrument-the test items, survey questions or other measurement tools".

Sementara validitas konstruk menunjuk pada sejauh mana suatu instrumen mampu mengukur pengertian-pengertian yang terkandung dalam materi yang akan diukur (Uno, 2001: 140). Validitas konstruk ditentukan oleh ketepatan dan kecermatan pengukuran. Prosedur pengujian validitas konstruk berangkat dari hasil komputasi interkorelasi di antara berbagai hasil tes dan kemudian diikuti oleh analisis lebih lanjut terhadap matriks korelasi yang diperoleh, melalui berbagai metode. 
Magnusson sebagaiman dikutip oleh Azwar (2008: 132), menjelaskan, bahwa apabila kita ingin melakukan rating terhadap sifat agresivitas yang tampak, kita akan melakukannya setelah melaksanakan observasi terhadap perilaku target beberapa lamanya. Biasanya, rating terhadap perilaku sedemikian itu menjadi indikator yang valid bagi ada-tidaknya sifat agresivitas. Akan tetapi, bila kita ingin mengungkapkan atau mengukur adanya agresivitas yang laten (yang belum tampak manifestasinya dalam perilaku) maka kita melakukannya lewat suatu tes projektif, tidak lewat observasi.

Menurut Sudjana (2005: 14), validitas konstruk berkenaan dengan kesanggupan alat penilaian untuk mengukur pengertian-pengertian yang terkandung dalam materi yang diukurnya. Pengertian-pengertian yang terkandung dalam konsep kemampuan, minat, sikap dalam berbagai bidang kajian harus jelas apa yang hendak diukurnya. Konsep-konsep tersebut masih abstrak, memerlukan penjabaran yang lebih spesifik sehingga mudah diukur.

Suryabrata (2005: 42) menjelaskan validitas konstruk (construct validity) mempersoalkan sejauh mana skor-skor hasil pengukuran dengan suatu instrumen merefleksikan konstruk teoritik yang mendasari penyusunan alat ukur tersebut. Dua di antara pendekatan yang banyak dilakukan dalam pengujian validitas konstruk antara lain adalah pendekatan multitraitmultimethode dan pendekatan confirmatory factor analysis.

Tujuan dari validitas konstruk adalah untuk membuktikan apakah hasil pengukuran yang diperoleh melalui item-item tes berkorelasi tinggi dengan konstruk teoretik yang mendasari penyusunan tes tersebut. Apakah skor yang diperoleh mendukung konsep teoretik yang diinginkan oleh tujuan pengukuran semula, (Azwar, 2012: 1160). Cronbach dalam Azwar menulis, bahwa untuk menguji validitas konstrak melibatkan paling tidak tiga langkah, yaitu a) mengartikulasikan serangkaian konsep teoretik dan interrelasinya, b) mengembangkan cara untuk mengukur konstrak hipotetik yang diteorikan, dan c) menguji secara empirik hubungan hipotetik di antara konstrak tersebut dan manifestasinya yang nampak. 
Analisis faktor merupakan model yang pertama kali dikembangkan sebagai suatu metode untuk mengkaji sesuatu yang tidak dapat diamati. Seperti intelegensi, motivasi, kemampuan, sikap, dan opini, (Raykov, 2006: 116). Analisis faktor dibagi menjadi dua macam yaitu analisis komponen utama (principal component analysis $=$ PCA) dan analisis faktor (factor analysis $=\mathrm{FA}$ ). Kedua analisis ini bertujuan menerangkan struktur ragam-ragam melalui kombinasi linier dari variabel-variabel pembentuknya. Sehingga dapat dikatakan bahwa faktor atau komponen adalah variabel bentukan bukan variabel asli.

Perbedaan keduanya, dalam pandangan Steward (2001: 1) meliputi: bahwa kedua model analisis tersebut didasarkan pada perbedaan teori yang mendasarinya. Analisis faktor itu digunakan untuk mengelompokkan variabel-variabel yang memiliki korelasi yang relatif tinggi dan berdistribusi multivariat normal. Kelompok-kelompok yang dihasilkan oleh analisis faktor nantinya independen satu dengan lainnya. Selain itu dalam analisis faktor variabel yang berada dalam satu kelompok memiliki korelasi yang tinggi dengan variabel lain dan variabel yang berada di kelompok yang berbeda cenderung memiliki korelasi yang rendah.

Analisis faktor sekilas sama dengan analisis komponen utama, meskipun demikian ada perbedaan di antara keduanya. Analisis faktor merupakan analisis yang tidak hanya mengelompokkan saja namun mengkonfirmasi ulang kelompokkelompok yang di dapat dengan teori yang ada. Sedangkan analisis komponen utama mengelompokkan variabel-variabel yang pada awalnya memiliki korelasi yang tinggi menjadi kelompokkelompok yang disebut PC (principal component, komponen utama), dimana masing-masing tersebut sudah independen.

Analisis komponen utama biasanya dipakai sebagai analisis yang tidak berdiri sendiri sebagai contoh apabila di dalam analisis regresi terjadi multikolinieritas maka variabel-variabel yang memiliki korelasi yang tinggi tersebut dapat dianalisis komponen utama sehingga menghasilkan variabel baru yang disebut principal component, yang telah independen nantinya dapat diregresikan sehingga asumsi tidak terjadi multikolinieritas dapat terpenuhi. 
Analisis faktor berfungsi melayani tujuan keiritan upaya ilmiah. Ia mengurangi kelipatgandaan tes dan pengukuran hingga menjadi jauh lebih sederhana, (Kerlinger, 2004: 1000). Alhasil, analisis faktor memberitahu kita tes-tes dan ukuran-ukuran yang saling dapat serasi atau sama tujuannya, dan sejauh manakah kesamaan itu. Dengan demikian, ia mengurangi banyaknya variabel yang harus ditangani. Suatu faktor adalah sebuah konstruk, suatu utuhan hipotesis, variabel laten yang dianggap melandasi tes, skala, butir, dan bahkan hampir semua jenis ukuran.

Tujuan utama analisis faktor adalah untuk menjelaskan struktur hubungan di antara banyak variabel dalam bentuk faktor atau variabel laten atau variabel bentukan. Faktor yang terbentuk merupakan besaran acak (random quantities) yang sebelumnya tidak dapat diamati atau diukur atau ditentukan secara langsung.

Mengukur instrumen dengan menggunakan pendekatan Confirmatory Factor Analysis (CFA) adalah teknik yang mendominasi penggunaan pengukuran untuk mengembangkan struktur sebuah faktor yang valid. Legitimasi penggunaan CFA sudah tentu menjadi faktor yang mengikat dari konsep yang rasional, sepertihalnya pendekatan hipotesis sebagai data analisis.

Analisis faktor konfirmatori merupakan alat ukur yang paling tepat untuk diterapkan pada langkah-langkah yang telah sepenuhnya dikembangkan dan terstruktur pada faktor yang telah divalidasi, (Byrne: 1998: 136). Legitimasi penggunaan CFA, tentu saja, terkait dengan pemikiran konseptual sebagai pendekatan pengujian hipotesis untuk analisis data. Model konfirmatori digunakan untuk menguji teori atau menyelidiki hipotesis perbedaan dalam "latent process" antara grup-grup pada subyeksubyek. Model konfirmatori digunakan untuk mengkonfirmasikan sejumlah dimensi/indikator/faktor yang mendasari penelitian.

Langkah-langkah yang diperlukan dalam analisis faktor adalah sebagai berikut:

1. Merumuskan Masalah. Dalam hal ini, merumuskan masalah meliputi: (a) tujuan analisis faktor harus diidentifikasi. (b) variabel yang akan dipergunakan di dalam analisis faktor harus dispesifikasi berdasarkan penelitian sebelumnya, teori dan pertimbangan peneliti. (c) pengukuran variabel 
berdasarkan skala interval atau rasio. (d) banyaknya elemen sampel (n) harus cukup/memadai, sebagai petunjuk kasar, kalau $k$ banyaknya jenis variabel (atribut) maka $n=4$ atau 5 kali k. (Supranto, 2010: 122).

2. Bentuk matrik korelasi. Proses analisis ini pada dasarnya didasarkan pada matriks korelasi di antara variabelvariabelnya. Analisis faktor baru dapat dilakukan bila variabel-variabelnya saling berhubungan satu dan lainnya, karena salah satu tujuan dari dilakukannya analisis faktor adalah untuk membantu menerangkan adanya korelasi tersebut. Matrik korelasi yang digeneralisasikan untuk semua butir (sebagai variabel) dan membentuk urutan koefisien korelasi satu sama lain. Untuk menguji kelayakan tersebut, dapat diuji melalui:

a. Bartlett's test of sphericity adalah sebuah test statistic yang digunakan untuk menguji hipotesa variabel yang tidak berkorelasi dengan populasi. Dengan kata lain, matriks korelasi populasinya adalah sebuah identity matrix. Setiap variabel yang berhubungan sempurna dengan variabel tersebut bernilai $r=1$, sementara variabel yang tidak mempunyai korelasi dengan varibel lainnya bernilai $\mathrm{r}=0$.

b. Kaiser-Meyer-Okin Measures of Sampling Adequacy (KMO MSA) merupakan suatu indeks untuk membandingkan koefisien korelasi sampel (yang diobservasi) koefisien parsial, dengan kriteria aturan Kaiser seperti dikutip Norusis bahwa, KMO MSA $\geq 0.90$ adalah baik sekali (marvelous), $\geq 0.80$ baik (meritorious), $\geq 0.70$ harga menengah (middling), $\geq$ 0.60 cukup (mediocre), $\geq 0.50$ kurang memuaskan (miserable) dan di bawah 0.50 tidak dapat diterima (unacceptable).

3. Menentukan Metode Analisis Faktor. Terdapat dua cara yang bisa dipergunakan dalam analisis faktor, khususnya untuk menghitung koefisien skor faktor, yaitu principal component analysis dan common factor analysis. (Thompson, 2002: 36) 
4. Menentukan banyaknya faktor berdasarkan nilai eigenvalues yang menunjukan besarnya sumbangan dari faktor terhadap seluruh variabel asli.

5. Merotasikan faktor. Dalam hal ini metode yang akan digunakan adalah rotasi varimax, suatu metode yang meminimisasi jumlah variabel yang memiliki loading yang tinggi pada tiap faktornya. (Djaali, 2008: 84), dengan tujuan memaksimalkan hubungan antara variabel dengan beberapa iterasi atau putaran. Faktor matrix memuat koefisien-koefisien yang digunakan untuk menjelaskan standarisasi variabel-variabel yang berkenaan dengan faktor-faktor. Koefisien ini, yang disebut dengan factor loading, yaitu menerangkan korelasi antara faktor-faktor dan variabel-variabel.

6. Selanjutnya diekstraksi kembali dengan metode konfirmatori menggunakan teknik kebolehjadian maksimum (maximum likelihood/ML) yang merupakan metode untuk mengestimasi parameter bahwa sampel berdistribusi normal multivariat, untuk menentukan kesesuaian model, (Hardel dan Hlavka, 2007: 186). Hal itu menunjukkan secara ekplisit perbedaan antara korelasi dari variabel yang diamati, dan nilai hipotesis dari sampel secara menyeluruh.

Sebutan lain dari Confirmatory factor analysis dikenal juga dengan istilah Structural Equation Modeling SEM. Model persamaan struktural adalah merupakan metode statistik yang komprehensif, untuk menguji hipotesis tentang suatu hubungan antara variabel teramati dan variabel laten, (Hoyle, 1995: 1). Model persamaan struktural menurut Latan (2012:2) merupakan perkembangan dari analisis faktor dan analisis jalur. SEM merupakan kombinasi metodologi dua disiplin ilmu, yaitu model analisis faktor konfirmatori (confirmatory factor analysis model) yang diambil dari psychometric dan model persamaan struktural yang diambil dari econometrics.

Model persamaan struktural adalah metodologi statistik yang mengambil pendekatan konfirmatori untuk analisis multivariat teori struktural pada beberapa fenomena. Model 
persamaan struktural, menurut Schumacker dan Lomax (1996: 2) seperti metode statistik lainnya, melibatkan pengukuran kedua variabel teramati independen dan dependen. Variabel ini digunakan untuk mendefinisikan kedua variabel laten independen dan dependen yang tidak dapat diukur secara langsung tetapi bukan disimpulkan dari hipotesis dari variabel yang diamati.

Analisis SEM terdiri dari dua sub model yaitu model pengukuran (measurement model) atau sering disebut outer model dan model struktural (structural model) atau sering disebut innear model. Model pengukuran menujukkan bagaimana variabel manifest atau observed variable merepresentasi variabel laten untuk diukur. Sedangkan model struktural menujukkan kekuatan estimasi antar variabel laten atau konstruk. Menurut Latan (2012: 2), SEM lebih mengutamakan pengujian confirmatory dibandingkan dengan exploratory sehingga lebih tepat digunakan untuk menguji teori dibandingkan dengan mengembangkan teori.

Model persamaan struktural (MPS) meliputi seluruh model yang terkenal dengan banyak nama seperti: covariance structure analysis, latent variable analysis, confirmatory factor analysis, dan sering disebut lisrel analysis. (Supranto, 2010: 221). Dalam SEM, unobserved variable sering disebut juga dengan istilah variabel laten. Variabel laten merupakan variabel yang tidak dapat diukur secara langsung tetapi melalui indikator atau manifest varibelnya (Kline, 2011: 9).

Langkah langkah dalam SEM menurut Hair (2010: 654) di antaranya: (1) pengembangan model berbasis teori, (2) mengkonstruksi diagram jalur untuk hubungan kausal, (3) mengkonversi diagram jalur ke dalam model struktural dan model pengukuran, (4) memilih matriks input dan estimasi model, (5) menilai identifikasi model struktural, (6) evaluasi kecocokan model berdasarkan kriteria goodness-of-fit dan (7) interpretasi dan modifikasi model.

Menurut Kline (2011: 9), setidaknya terdapat beberapa proses yang dilalui dalam analisis Covariance Based SEM di mana setiap tahapan akan berpengaruh terhadap tahapan selanjutnya, yaitu: (1) spesifikasi model, (2) identifikasi model, (3) estimasi model, (4) evaluasi model dan (5) respesifikasi model. Spesifikasi 
model merupakan langkah awal dalam analisis SEM. Pada tahap ini peneliti harus mendefinisikan secara konseptual konstruk yang diteliti dan menentukan dimensionalitasnya. Identifikasi model bertujuan untuk mengetahui model yang dibangun dengan data empiris yang dikumpulkan, apakah memiliki nilai yang unik atau tidak, sehingga model tersebut dapat diestimasi. Model dalam CB-SE terdapat setidaknya tiga pilihan model estimasi yang sering digunakan, yaitu: Maximum likelihood (ML), Generalized Least Square (GLS), dan Asymptotically Distribution Free (ADF).

Evaluasi model bertujuan untuk mengevaluasi model secara keseluruhan, apakah model mempunyai fit yang baik ataukah tidak. Evaluasi model dalam CB-SEM dapat dilakukan dengan menilai hasil pengukuran model (measurement model) yaitu melalui analisis faktor konfirmatori dengan menguji validitas dan reliabilitas konstruk laten kemudian dilanjutkan dengan evaluasi model struktural (structural model) secara keseluruhan dengan menilai kelayakan model melalui kriteria goodness of fit.

Selain ketepatan alat ukur, instrumen kecerdasan spiritual juga dituntut kemantapan atau keajegan dari hasil ukur tersebut. Karena itu reliabilitas menunjukan pada konsistensi sekor pada subyek yang sama, saat diuji ulang dengan tes yang sama pada kesempatan yang berbeda, atau dengan tes yang eqiuvalen. Dengan demikian reliabilitas menunjukan sebuah konsistensi hasil yang didapat oleh responden pada beberapa kali dilakukan pengujian. Pengujian reliabilitas dapat dilakukan dengan menggunakan koefisien reliabilitas Alpha Cronbach Berstrata.

\section{Simpulan}

Setiap penelitian, baik yang bersifat kuantitatif, kualitatif, maupun pengembangan (research development) tidak terlepas dari instrumen sebagai alat pengmpul data. Alat pengumpul data yang lazim digunakan berupa kuesioner, tes, wawancara, observasi, maupun dokumentasi, sangat bergantung kepada jenis data apa yang kita butuhkan, serta kesesuaiannya dengan teknik analisis datanya.

Mengembangkan suatu instrumen dengan prosedur dan metode yang sesuai merupakan keniscayaan. Secara konseptual, 
bahwa mengembangkan instrumen kognitif dan non kognitif merupakan kegiatan yang relatif sama ditinjau dari segi tahapan, prosedur, dan teknik pengujiannya.

Hasil penelitian menujukkan bahwa; pertama, instrumen memegang peranan yang sangat penting dalam menentukan mutu suatu penelitian, sekaligus alat bantu yang digunakan oleh peneliti untuk mengumpulkan data dengan cara melakukan pengukuran. Kedua, prosedur pengembangan instrumen melewati beberapa tahap, mulai dari tahap mengembangkan definisi konseptual, pemberian skala, rewiew justifikasi butir, menyiapkan draf isntrumen, pengumpulan data uji coba, dan analisis data ujicoba. Ketiga, metode pengujian yang digunakan untuk mengembangkan instrumen adalah analisis faktor dengan menggunakan bantuan soft ware SPSS dan Lisrel. 


\section{DAFTAR PUSTAKA}

Abdul Aziz, Albelaikhi, 1998. Development of Moslem Religiosity Scale, North Zeeb Road: UMI Company.

Abel, Neil dan David W. Springer, 2009. Developing and Validating Rapid Instrument, New York: Oxford University Press.

Azwar, Saifuddin, 2012. Reliabilitas dan Validitas, Jogjakarta: Pustaka Pelajar.

Pustaka Pelajar.

2005. Dasar-Dasar Psikometri, Yogyakarta:

Byrne, Barbara M., 1998. Structural Equation Modeling with Lisrel, Prelis, and Simplis, New Jersey: Lawrence Erlbaum Associate, Publisher.

Camic, Paul M., 2003. Qualitative Research in Psychology Expanding Perspective and Design, Washington, DC: American Psychology Association.

Colton, David dan Robert W. Covert, 2007. Designing and Constructing Instruments for Social Research and Evaluation, San Francisco: Jossey-Basse.

David Steward, "Difference Between Principal Components and Factor Analysis," Journal of Consumer Psychology Lawrence Erlbaum Associates, Vol. 10, No.1, 2001.

Djaali, dan Pudji Muljono, 2008. Pengukuran dalam Bidang Pendidikan, Jakarta: Grasindo.

Gable, Robert K., 1986. Instrument Development in The Affective Domain, Buston: Kluwer-Nijhoff Publishing.

Hadi, Sutrisno, 1986. Metodology Research, Jogjakarta: UGM.

Hair, JR., Joseph F., 2010. Multivariate Data Analysis a Global Perspective, New Jersey: Pearson Education.

Haladyna, Thomas M., 2004. Developing and Validating MultipleChoice Test Item, New Jersey: Lawrence Elbaurm Associate Publisher.

Hardel, Wolfgang dan Zdenek Hlavka, 2007. Multivariate Statistic Exercises and Solution, Berlin: Springer. 
Harrington, Donna, 2009. Confirmatory Factor Analysis, New York: Oxford University Press.

Hoyle, Rick H., 1995. Structural Equation Modeling Concepts Issues and Application, London: SAGE Publication.

Kerlinger, Fred N., 2004. Asas-Asas Penelitian Behaviorial, terjemahan Landung N. Simatupang Jogjakarta: Gajah Mada University Press.

Kline, Rex B., 2011. Principles and Practice of Structural Equation Modeling, New York: The Guilford Press.

Kothari, C. R., 2004. Research Methodology, New Delhi: New Age International Publisher.

Latan, Hengky. 2012. Structural Equation Modeling Konsep dan Aplikasi, Bandung: Alfabeta.

Patton, Michael Quinn, 1990. Qualitative Evaluation and Research Methods, New Delhi: International Education and Professional Publisher

Purwanto, 2010. Metodologi Penelitian Kuantitatif, Yogyakarta: Pustaka Pelajar.

Robinson Kurpius, Sharon E., 2006. Testing and Measurement, California: SAGE Publication.

Raykov, Tenko, 2006. A First Course in Structural Equation Modeling, New Jersey: Lawrence Erlbaum Associates Publisher.

Semiawan, Conny R., 2008. Catatan Kecil tentang Penelitian dan Pengembangan Ilmu Pengetahuan, Jakarta: Kencana Prenada Media Group.

Sian Cotton dan Meghan E. McGrady, "Measurement of Religiosity in Adolescent Health Outcome Research: Trends and Recommendations," Journal Religion Health, Vol. 10, No. 1, 2010: 433-435.

Sion Kim Harris dan Lydia A. Shrier, "Reliability and Validity of the Brief Multidimensional Measure of Religiousness/ Spirituality among Adolescent," Journal Religion Health, Vol. 10, No. 1, 2007. 
Schumacker Randall E., dan Richard G. Lomax, 1996. Begginers Guide to Structural Equation Modeling, New Jersey: Lawrence Erlbaum Associates Publisher.

Sudjana, Nana, 2005. Penilaian Hasil Proses Belajar Mengajar, Bandung: PT Remaja Rosda Karya.

Supranto, J., 2010. Analisis Multivariat, Jakarta: Rineka Cipta.

Suprayogo, Imam, 2003. Metodologi Penelitian Sosial-Agama, Bandung: Rosda Karya.

Suryabrata, Sumadi, 2005. Alat Ukur Psikologis, Yogyakarta: Andi.

Thompson, Bruce, 2002. Exploratory and Confirmatory Factor Analysis, Washington, DC: American Psychological Association.

Uno, Hamzah B., 2001. Pengembangan Instrumen untuk Penelitian, Jakarta: Delima Press.

Zohar, D., dan Marshall, I, 2007. Kecerdasan Spiritual, Bandung: Mizan. 
Rijal Firdaos 